\title{
MANAGING CONTROL OBJECT FOR IT (COBIT) SEBAGAI STANDAR FRAMEWORK PADA PROSES PENGELOLAAN IT-GOVERNANCE DAN AUDIT SISTEM INFORMASI
}

\author{
Deni Setiawan \\ 195100057p \\ Fakultas Sistem Informasi, Universitas Mitra, \\ Bandar Lampung \\ E-mail : deni.student@umitra.ac.id
}

\begin{abstract}
ABSTRAK
COBIT merupakan a set of best practice (framework) bagi pengelolaan teknologi informasi (IT management) yang secara lengkap terdiri dari: executive summary, framework, control objectives, audit guidelines, implementation tool set serta management guidelines yang sangat berguna untuk proses sistem informasi strategis.

COBIT berguna bagi IT users dalam memperoleh keyakinan atas kehandalan sistem aplikasi yang dipergunakan. Sedangkan para manajer memperoleh manfaat dalam keputusan saat menyusun strategic IT plan, menentukan information architecture,dan keputusan atas procurement (pengadaan/pembelian) inventaris organisasi.

IT governance memastikan adanya pengukuran yang efisien dan efektif terhadap peningkatan proses bisnis perusahaan melalui struktur yang menggunakan proses-proses TI, sumberdaya TI dan informasi ke arah dan tujuan strategis perusahaan dengan menggunakan metode penilaian (scoring) sehingga suatu organisasi dapat menilai proses-proses TI yang dimilikinya dari skala nonexistent sampai dengan optimised (dari 0 sampai 5).

Dari studi literatur ini terlihat bahwa COBIT mempunyai spektrum proses TI yang luas dan lebih mendetail serta lebih mendalam dalam mendefinisikan proses-proses TI yang bersifat teknis dan operasional bila dibandingkan dengan COSO atau ITIL.
\end{abstract}

Kata kunci : COBIT, IT Governance, IT Governance

\section{PENDAHULUAN}

\subsection{COBIT}

COBIT merupakan a set of best practice (framework) bagi pengelolaan teknologi informasi (IT management). COBIT disusun oleh The IT Governance Institute (ITGI) dan Information System Audit and Control Association (ISACA) pada tahun 1992. Edisi pertama dipublikasikan pada tahun 1996, edisi kedua pada tahun 1998, edisi ketiga tahun 2000 (versi on- line dikeluarkan tahun 2003) dan saat ini adalah edisi keempat pada desember 2005. Paket COBIT secara lengkap terdiri dari : executive summary, ramework, control objectives, audit guidelines, implementation tool set serta management guidelines yang sangat berguna dan dibutuhkan oleh auditor, para IT users, dan para manajer, seperti ditunjukkan pada gambar 1.0 berikut : 


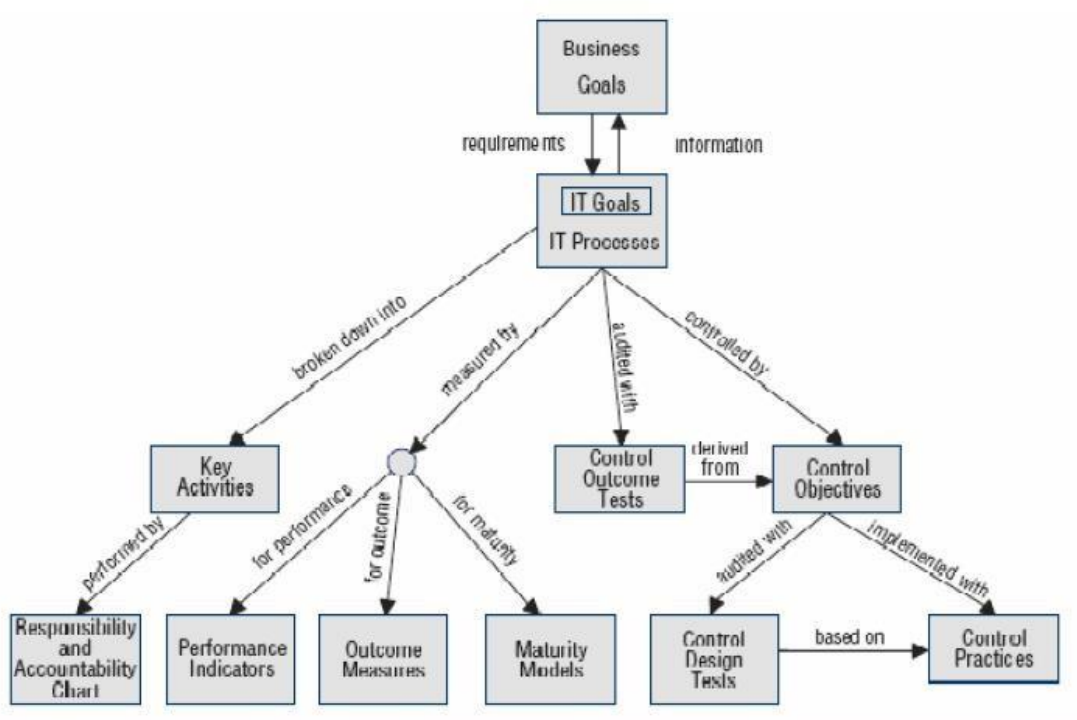

Gambar 1.0 Hubungan antara komponen COBIT

COBIT adalah sekumpulan dokumentasi best practices untuk IT Governance yang dapat membantu auditor, pengguna (user), dan manajemen, untuk menjembatani gap antara risiko bisnis, kebutuhan control dan masalah-masalah teknis TI. COBIT bermanfaat bagi auditor karena merupakan teknik yang dapat membantu dalam identifikasi IT controls issues. COBIT berguna bagi IT users karena memperoleh keyakinan atas kehandalan sistem aplikasi yang dipergunakan. Sedangkan para manajer memperoleh manfaat dalam keputusan investasi di bidang TI serta infrastrukturnya, menyusun strategic IT plan, menentukan information architecture, dan keputusan atas procurement (pengadaan/pembelian) mesin. Untuk lebih jelasnya dapat dilihat pada gambar 1.1.

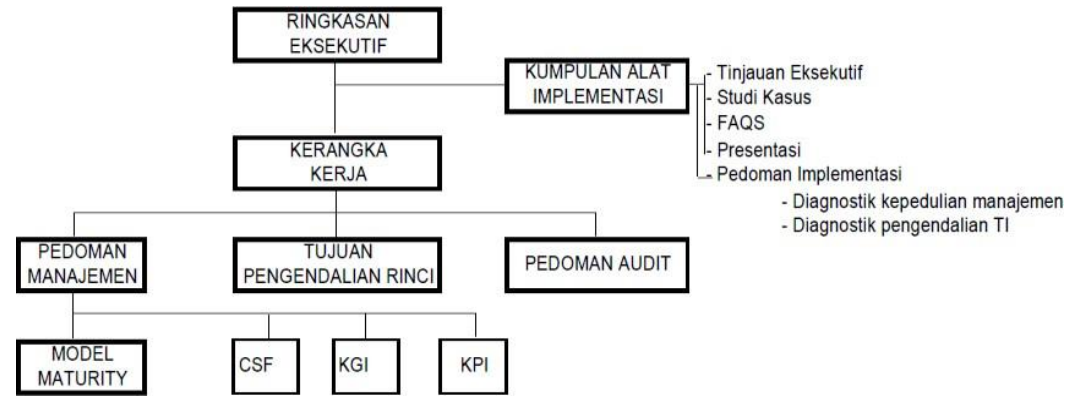

Gambar 1.1 Produk Keluarga COBIT Framework 
COBIT dapat dipakai sebagai alat yang komprehensif untuk menciptakan IT Governance pada suatu perusahaan. COBIT mempertemukan dan menjembatani kebutuhan manajemen dari celah atau gap antara risiko bisnis, kebutuhan kontrol dan masalah-masalah teknis TI, serta menyediakan referensi best business practices yang mencakup keseluruhan TI dan kaitannya dengan proses bisnis perusahaan dan memaparkannya dalam struktur aktivitas-aktivitas logis yang dapat dikelola serta dikendalikan secara efektif, yang dapat digambarkan melalui gambar 1.2 kerangka kerja tujuan control teknologi informasi di bawah ini:

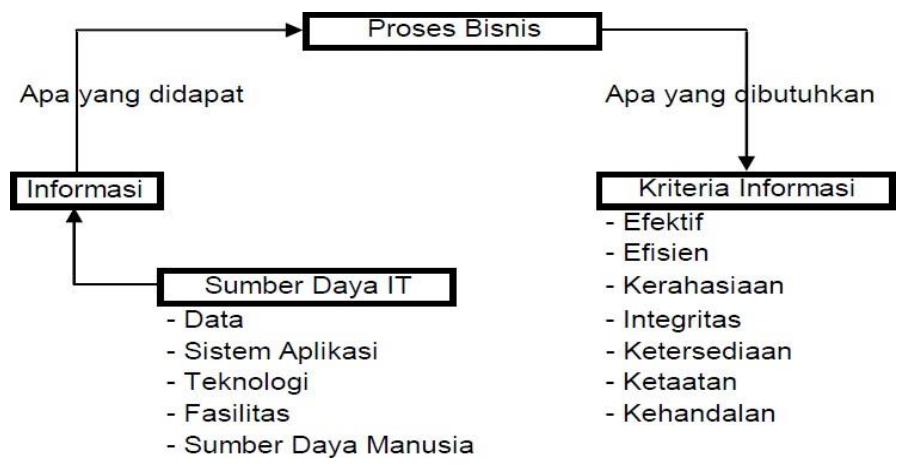

Gambar 1.2 Kerangka Kerja Tujuan Kontrol Teknologi Informasi

COBIT mendukung manajemen dalam mengoptimumkan investasi TI-nya melalui ukuranukuran dan pengukuran yang akan memberikan sinyal bahaya bila suatu kesalahan atau risiko akan atau sedang terjadi. Manajemen harus memastikan bahwa sistem kendali internal perusahaan bekerja dengan baik, artinya dapat mendukung proses bisnis perusahaan yang secara jelas menggambarkan bagaimana setiap aktivitas kontrol individual memenuhi tuntutan dan kebutuhan informasi serta efeknya terhadap sumberdaya TI perusahaan. Sumberdaya TI merupakan suatu elemen yang sangat disoroti COBIT, termasuk pemenuhan kebutuhan bisnis terhadap : efektivitas, efisiensi, kerahasiaan, keterpaduan, ketersediaan, kepatuhan pada kebijakan/aturan dan keandalan informasi (effectiveness, efficiency, confidentiality, integrity, availability, compliance, dan reliability).

Kriteria kerja COBIT meliputi :

Tabel 1.1 Kriteria kerja COBIT

\begin{tabular}{|l|l|}
\hline Efektifitas & $\begin{array}{l}\text { Untuk memperoleh informasi yang relevan dan berhubungan dengan } \\
\text { proses bisnis seperti penyampaian informasi dengan } \\
\text { benar, konsisten, dapat dipercaya dan tepat waktu. }\end{array}$ \\
\hline Efisiensi & $\begin{array}{l}\text { Memfokuskan pada ketentuan informasi melalui penggunaan sumber } \\
\text { daya yang optimal. }\end{array}$ \\
\hline Kerahasiaan & Memfokuskan proteksi terhadap informasi yang penting dari orang \\
\hline
\end{tabular}




\begin{tabular}{|l|l|}
\hline & yang tidak memiliki hak otorisasi. \\
\hline Integritas & $\begin{array}{l}\text { Berhubungan dengan keakuratan dan kelengkapan informasi sebagai } \\
\text { kebenaran yang sesuai dengan harapan dan nilai } \\
\text { bisnis. }\end{array}$ \\
\hline Ketersediaan & $\begin{array}{l}\text { Berhubungan dengan informasi yang tersedia ketika diperlukan } \\
\text { dalam proses bisnis sekarang dan yang akan datang. }\end{array}$ \\
\hline Kepatuhan & $\begin{array}{l}\text { Sesuai menurut hukum, peraturan dan rencana perjanjian untuk } \\
\text { proses bisnis. }\end{array}$ \\
\hline Keakuratan informasi & $\begin{array}{l}\text { Berhubungan dengan ketentuan kecocokan informasi untuk } \\
\text { manajemen mengoperasikan entitas dan mengatur pelatihan } \\
\text { keuangan dan kelengkapan laporan pertanggungjawaban. }\end{array}$ \\
\hline
\end{tabular}

Dalam kerangka corporate governance, IT governance menjadi semakin utama dan merupakan bagian tidak terpisahkan terhadap kesuksesan penerapan corporate governance secara menyeluruh. IT governance memastikan adanya pengukuran yang efisien dan efektif terhadap peningkatan proses bisnis perusahaan melalui struktur yang menggunakan proses-proses TI, sumberdaya TI dan informasi ke arah dan tujuan strategis perusahaan. Lebih jauh lagi, IT governance memadukan dan melembagakan best practices dari proses perencanaan, pengelolaan, penerapan, pelaksanaan dan pendukung, serta pengawasan kinerja TI, untuk memastikan informasi perusahaan dan teknologi yang terkait yang terkait lainnya benar-benar menjadi pendukung bagi pencapaian sasaran perusahaan. Dengan keterpaduan tersebut, diharapkan perusahaan mampu mendayagunakan informasi yang dimilikinya sehingga dapat mengoptimumkan segala sumberdaya dan proses bisnis mereka untuk menjadi lebih kompetitif.

Dengan adanya IT governance, proses bisnis perusahaan akah menjadi jauh lebih transparan, tanggungjawab serta akuntabilitas setiap fungsi/individu semakin jelas. IT governance bukan hanya penting bagi teknisi TI saja, direksi dan bahkan komisaris, yang bertanggungjawab terhadap investasi dan pengelolaan risiko perusahaan adalah pihak utama yang harus memastikan bahwa perusahaannya memiliki IT governance. Dengan demikian keuntungan optimum investasi TI tercapai, dan sekaligus memastikan semua potensi risiko investasi TI telah diantisipasi dan dapat terkendali dengan baik.

COBIT mendefiniskan Control objective TI sebagai pernyataan mengenai hasil atau tujuan yang harus dicapai melalui penerapan prosedur kendali dalam aktivitas TI tertentu. Pada edisi keempat ini COBIT framework terdiri dari 34 high level control objectives dikelompokkan dalam 4 domain utama:

\section{Planning \& Organisation.}

Domain ini menitikberatkan pada proses perencanaan dan penyelarasan strategi TI dengan strategi perusahaan. 
2. Acquisition \& Implementation.

Domain ini menitikberatkan pada proses pemilihan, pengadaaan dan penerapan teknologi informasi yang digunakan.

3. Delivery \& Support.

Domain ini menitikberatkan pada proses pelayanan TI dan dukungan teknisnya.

4. Monitoring.

Domain ini menitikberatkan pada proses pengawasan pengelolaan TI pada organisasi.

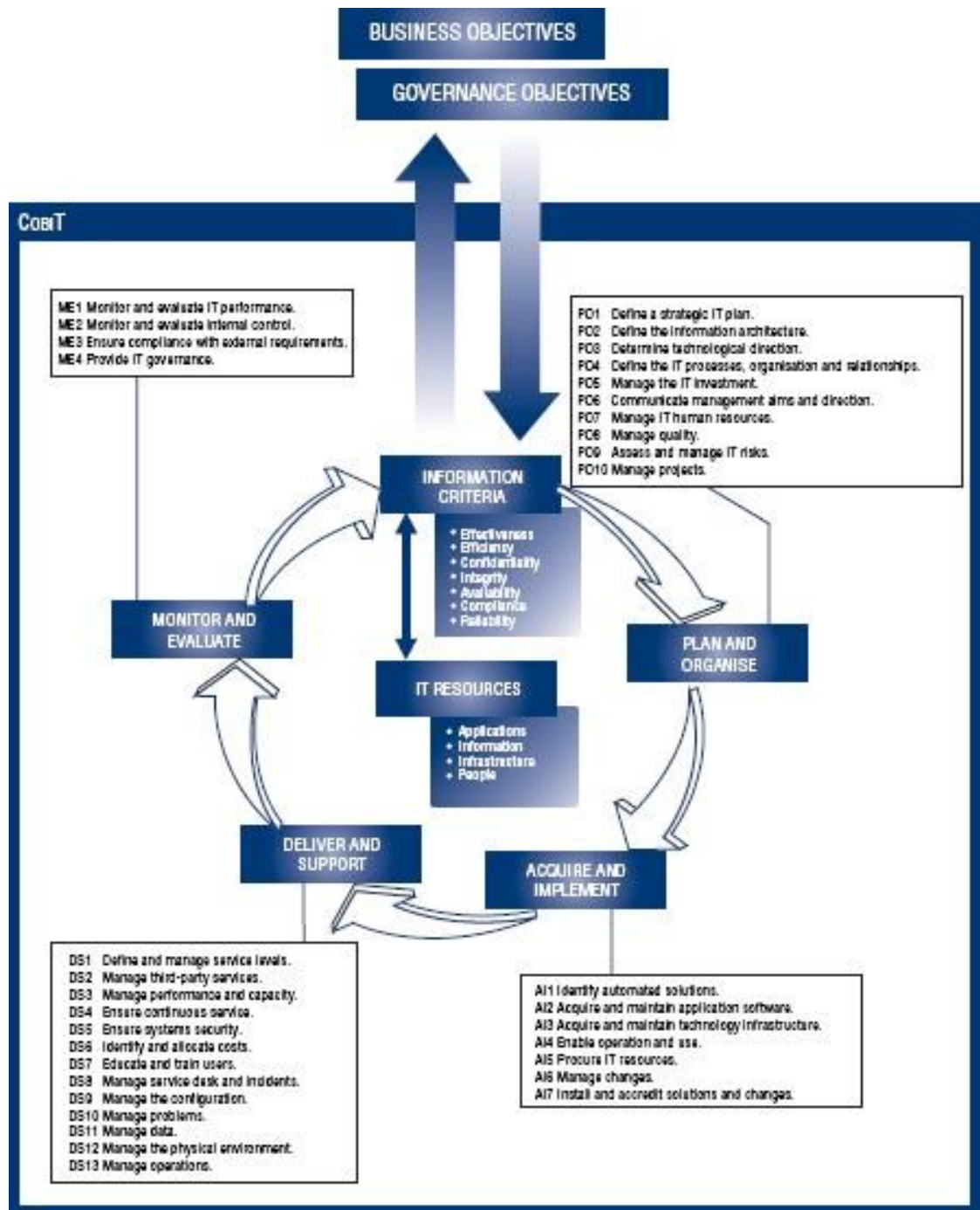

Gambar 1.3 COBIT Framework (COBIT 4.1 Excerp, Executive Summary Framework, 2008) 
Masing-masing domain terdiri dari high-level control-objectives sebagai berikut:

\section{Domain Planning \& Organization}
1. PO1 Define a Strategic TI Plan
2. $\mathrm{PO} 2$ Define the Information Architecture
3. $\mathrm{PO} 3$ Determine Technological Direction
4. PO4 Define the TI Organisation and Relationships
5. PO5 Manage the TI Investment
6. PO6 Communicate Management Aims and Direction
7. PO7 Manage IT Human Resources
8. $\mathrm{PO} 8$ Manage Quality
9. $\mathrm{PO} 9$ Assess and Manage IT Risks
10. PO10 Manage Projects

\section{Domain Acquisition \& Implementation}
1. AI1 Identify Automated Solutions
2. AI2 Acquire and Maintain Application Software
3. AI3 Acquire and Maintain Technology Infrastructure
4. AI4 Enable Operation and use
5. AI5 Procure IT Resources
6. AI6 Manage Changes
7. AI7 Install and Accredit Solutions and changes

\section{Domain Delivery \& Support}
1. DS1 Define and Manage Service Levels
2. DS2 Manage Third-party Services
3. DS3 Manage Performance and Capacity
4. DS4 Ensure Continous Services
5. DS5 Ensure System Security
6. DS6 Indentify and Allocate Cost
7. DS7 Educate and Train Users
8. DS8 Manage Service desk and incidents
9. DS9 Manage the Configurations
10. DS10 Manage Problems
11. DS11 Manage Data
12. DS12 Manage the Physical Environment
13. DS13 Manage Operations 


\section{Domain Monitoring}
1. M1 Monitor and Evaluate IT Performance
2. M2 Monitor and Evaluate Internal Control
3. M3 Ensure Compliance with external requirements
4. M4 Provide IT Governance

COBIT mempunyai model kematangan (maturity models) untuk mengontrol proses- proses TI dengan menggunakan metode penilaian (scoring) sehingga suatu organisasi dapat menilai prosesproses TI yang dimilikinya dari skala non-existent sampai dengan optimised (dari 0 sampai 5). Maturity models ini akan memetakan:

1. Current status dari organisasi - untuk melihat posisi organisasi saat ini.

2. Current status dari kebanyakan industri saat ini - sebagai perbandingan.

3. Current status dari standar internasional - sebagai perbandingan tambahan.

4. Strategi organisasi dalam rangka perbaikan - level yang ingin dicapai oleh organisasi.

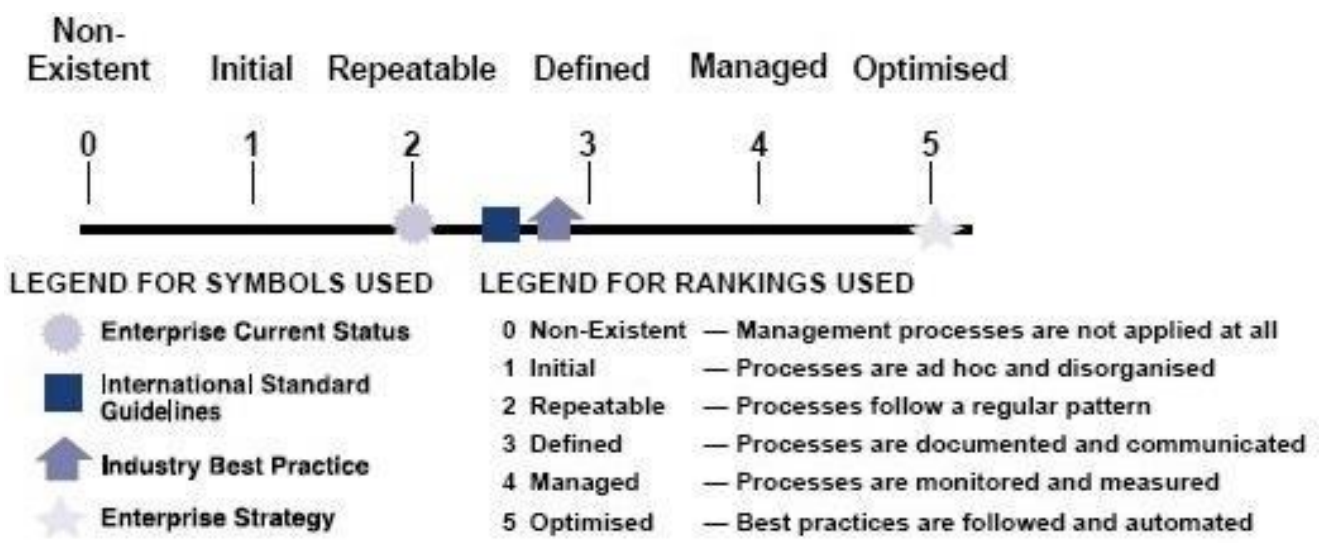

Gambar 1.4 COBIT Maturity Model (COBIT 4.1 Excerp, Executive Summary Framework, 2008)

Selain itu, COBIT juga mempunyai ukuran-ukuran lainnya sebagai berikut :

1. Critical Success Factors (CSF) - mendefinisian hal-hal atau kegiatan penting yang dapat digunakan manajemen untuk dapat mengontrol proses-proses TI di organisasinya.

2. Key Goal Indicators (KGI) - mendefinisikan ukuran-ukuran yang akan memberikan gambaran kepada manajemen apakah proses-proses TI yang ada telah memenuhi kebutuhan proses bisnis yang ada. KGI biasanya berbentuk kriteria informasi: 
a. Ketersediaan informasi yang diperlukan dalam mendukung kebutuhan bisnis.

b. Tidak adanya risiko integritas dan kerahasiaan data.

c. Efisiensi biaya dari proses dan operasi yang dilakukan.

d. Konfirmasi reliabilitas, efektifitas, dan compliance.

3. Key Performance Indicators (KPI) - mendefinisikan ukuran-ukuran untuk menentukan kinerja proses-proses TI dilakukan untuk mewujudkan tujuan yang telah ditentukan. KPI biasanya berupa indikator-indikator kapabilitas, pelaksanaan, dan kemampuan sumber daya TI.

Berikut ini adalah dasar penetapan maturity models :

Tabel 1.2 Dasar Penetapan Maturity Models

\begin{tabular}{|c|c|c|c|c|c|}
\hline Level & $\begin{array}{c}\text { Pengertian \& } \\
\text { Kesadaran }\end{array}$ & $\begin{array}{l}\text { Pelatihan \& } \\
\text { Komunikasi }\end{array}$ & $\begin{array}{l}\text { Proses \& } \\
\text { Aktivitas }\end{array}$ & Ketaatan & Keahlian \\
\hline 1 & Pengenalan & $\begin{array}{l}\text { Komunikasi } \\
\text { Jarang }\end{array}$ & $\begin{array}{l}\text { Proses dan } \\
\text { Aktivitas bersifat } \\
\text { Ad hoc }\end{array}$ & & \\
\hline 2 & Kesadaran & $\begin{array}{l}\text { Komunikasi } \\
\text { pada } \\
\text { keseluruhan } \\
\text { masalah }\end{array}$ & $\begin{array}{l}\text { Proses } \\
\text { serupa/umum tapi } \\
\text { berdasarkan } \\
\text { institusi }\end{array}$ & $\begin{array}{l}\text { Tidak } \\
\text { dilakukan } \\
\text { pemantauan }\end{array}$ & \\
\hline 3 & $\begin{array}{l}\text { Mengerti } \\
\text { kebutuhan untuk } \\
\text { bertindak }\end{array}$ & $\begin{array}{l}\text { Pelatihan } \\
\text { informal } \\
\text { berdasarkan } \\
\text { institusi } \\
\text { individu }\end{array}$ & $\begin{array}{l}\text { Aktivitas telah } \\
\text { didefinisikan dan } \\
\text { didokumentasikan }\end{array}$ & $\begin{array}{l}\text { Pemantauan } \\
\text { mulai } \\
\text { dilakukan } \\
\text { tidak secara } \\
\text { konsisten }\end{array}$ & $\begin{array}{l}\text { Terlibatnya } \\
\text { spesialis IT } \\
\text { pada proses } \\
\text { bisnis }\end{array}$ \\
\hline 4 & $\begin{array}{l}\text { Mengerti } \\
\text { kebutuhan secara } \\
\text { penuh }\end{array}$ & $\begin{array}{l}\text { Pelatihan } \\
\text { formal dengan } \\
\text { program yang } \\
\text { diatur }\end{array}$ & $\begin{array}{l}\text { Terdapat } \\
\text { kepemilikan\& } \\
\text { tanggung jawab } \\
\text { pada aktivitas }\end{array}$ & $\begin{array}{l}\text { Pemantauan } \\
\text { dilakukan } \\
\text { pada } \\
\text { beberapa area }\end{array}$ & $\begin{array}{l}\text { Terlibatnya } \\
\text { spesialis dari } \\
\text { semua } \\
\text { internal } \\
\text { domain }\end{array}$ \\
\hline 5 & $\begin{array}{l}\text { Pengertian yang } \\
\text { lebih baik dan ke } \\
\text { depan }\end{array}$ & $\begin{array}{l}\text { Pelatihan dan } \\
\text { komunikasi } \\
\text { menggunakan } \\
\text { konsep } \\
\text { leading edge }\end{array}$ & $\begin{array}{l}\text { Diterapkan } \\
\text { aktivitas yang } \\
\text { mendukung } \\
\text { kegiatan eksternal }\end{array}$ & $\begin{array}{l}\text { Pemantauan } \\
\text { dilakukan di } \\
\text { seluruh area }\end{array}$ & $\begin{array}{l}\text { Terlibatnya } \\
\text { spesialis } \\
\text { ekternal } \\
\text { industri }\end{array}$ \\
\hline
\end{tabular}

Penjelasan untuk Tingkat Maturity dapat dilihat pada Tabel 1.2 di bawah ini. 
Tabel 1.2 Tingkat Maturity

\begin{tabular}{|c|c|}
\hline \multicolumn{2}{|c|}{ Tingkat Maturity } \\
\hline Level 0 & $\begin{array}{l}\text { Tidak ada (Non-existent), organisasi belum mengenal isu permasalahan yang harus } \\
\text { diarahkan atau diselesaikan. Setiap proses atau masalah yang ada tidak terdefinisi } \\
\text { dengan jelas. }\end{array}$ \\
\hline Level 1 & $\begin{array}{l}\text { Inisialisasi (Initial), organisasi telah memiliki bukti telah mengenal permasalan- } \\
\text { permasalahan yang ada namun perlu diarahkan. Secara umum organisasi belum } \\
\text { memiliki standar pengelolaan yang terorganisir dan terdokumentasi dengan baik } \\
\text { sehingga perlu ada pendekatan yang dilakukan untuk tiap individu yang terkait dalam } \\
\text { organisasi. }\end{array}$ \\
\hline Level 2 & $\begin{array}{l}\text { Dapat diulang (Repetable), level ini sudah mengalami perkembangan, sudah ada } \\
\text { prosedur untuk menjalankan proses yang didefinisikan, namun belum ada pelatihan } \\
\text { formal dan prosedur komunikasi yang standar. Tanggung jawab dan } \\
\text { kepercayaan diberikan pada tiap individu tanpa ada standar baku pengopersian } \\
\text { sehingga kadang terjadi kesalahan. }\end{array}$ \\
\hline Level 3 & $\begin{array}{l}\text { Ditetapkan (Defined), sudah ada prosedur yang memiliki standar dan } \\
\text { didokumentasikan dengan baik, sudah ada pelatihan formal untuk mengkomunikasikan } \\
\text { prosedur dan kebijakan yang dibuat. Namun pada tahap implementasinya masih } \\
\text { tergantung pada individu apakah mau melakukan prosedur yang ditetapkan atau tidak. } \\
\text { Prosedur yang dibuat masih terbatas pada bentuk } \\
\text { formalisasi dari praktek yang ada. }\end{array}$ \\
\hline Level 4 & $\begin{array}{l}\text { Diatur (Managed), prosedur dan kebijakan yang ada sudah dilakukan secara efektif, } \\
\text { dapat dipantau dan diukur sehingga apabila terjadi kesalahan sudah memiliki sederetan } \\
\text { prosedur untuk tindakan perbaikan yang akan dilakukan. Perbaikan dilakukan secara } \\
\text { konsisten dan memberikan praktek dan hasil terbaik. Sudah digunakan peralatan dan } \\
\text { teknologi namun belum otomasi dan } \\
\text { masih terbatas. }\end{array}$ \\
\hline Level 5 & $\begin{array}{l}\text { Dioptimalkan (optimized), proses yang dilakukan telah dilakukan upaya perbaikan } \\
\text { yang berkelanjutan sehingga menghasilkan proses dan hasil yang terbaik. Sudah ada } \\
\text { penggunaan teknologi informasi yang terintegrasi untuk melakukan otomatisasi } \\
\text { dilingkungan organisasi, sudah tersedia alat dan pendukung lainnya yang dapat } \\
\text { meningkatkan kualitas dan efektifitas kinerja,dan organisasi sudah stabil dan dapat } \\
\text { beradaptasi dengan baik. }\end{array}$ \\
\hline
\end{tabular}

Sumber : COBIT 4.1, 2008 
Selain itu, COBIT juga mempunyai ukuran-ukuran lainnya sebagai berikut :

1. Critical Success Factors (CSF) - mendefinisian hal-hal atau kegiatan penting yang dapat digunakan manajemen untuk dapat mengontrol proses-proses TI di organisasinya dan faktor yang dibutuhkan untuk tercapainya kesuksesan yang optimal.

2. Key Goal Indicators (KGI) - mendefinisikan ukuran-ukuran yang akan memberikan gambaran kepada manajemen apakah proses-proses TI yang ada telah memenuhi kebutuhan proses bisnis yang ada. KGI biasanya berbentuk kriteria informasi:

a. Ketersediaan informasi yang diperlukan dalam mendukung kebutuhan bisnis.

b. Tidak adanya risiko integritas dan kerahasiaan data.

c. Efisiensi biaya dari proses dan operasi yang dilakukan.

d. Konfirmasi reliabilitas, efektifitas, dan compliance.

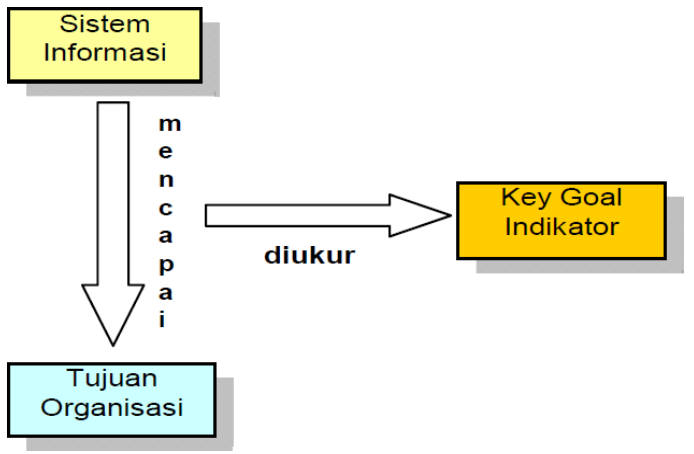

Gambar 1.5 Key Goal Indicator

3. Key Performance Indicators (KPI) - mendefinisikan ukuran-ukuran untuk menentukan kinerja proses-proses TI dilakukan untuk mewujudkan tujuan yang telah ditentukan. KPI biasanya berupa indikator-indikator kapabilitas, pelaksanaan, dan kemampuan sumber daya TI.
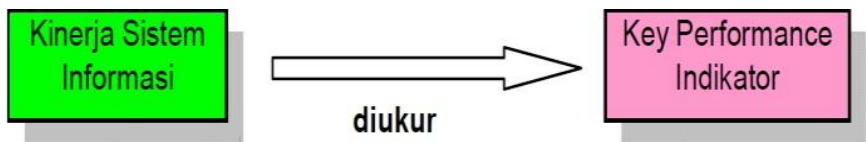

Gambar 1.6 Key Performance Indicator 


\section{PERBANDINGAN MODEL STANDAR TI GOVERNANCE}

\subsection{PERBANDINGAN COBIT DENGAN ITIL}

Tabel 2.1 menunjukkan bahwa ITIL sangat fokus kepada proses desain dan implementasi TI, serta pelayanan pelanggan (customer service), hal ini diperlihatkan bahwa hampir seluruh proses pada domain AI dan DS COBIT dilakukan.

Tabel 2.1 Matriks Proses COBIT vs Standar ITIL (COBIT Mapping, Overview of International IT Guidance, 2008)

\begin{tabular}{|l|l|l|l|l|l|l|l|l|l|l|l|l|l|}
\hline \multicolumn{1}{|c|}{ Proses dan Domain COBIT } \\
\hline & $\mathbf{1}$ & $\mathbf{2}$ & $\mathbf{3}$ & $\mathbf{4}$ & $\mathbf{5}$ & $\mathbf{6}$ & $\mathbf{7}$ & $\mathbf{8}$ & $\mathbf{9}$ & $\mathbf{1 0}$ & $\mathbf{1 1}$ & $\mathbf{1 2}$ & $\mathbf{1 3}$ \\
\hline PO & - & - & + & + & + & - & - & - & - & + & - & & \\
\hline AI & + & + & + & + & + & + & & & & & & & \\
\hline DS & + & + & + & + & + & + & - & + & + & + & + & + & + \\
\hline M & - & - & - & - & & & & & & & & & \\
\hline+ & Addressed \\
\hline
\end{tabular}

Sebagian proses PO dilakukan, ini menunjukkan bahwa ITIL tidak terlalu fokus pada proses penyelarasan strategi perusahaan dengan pengelolaan TI. Proses pada domain M sama sekali tidak dilakukan oleh ITIL, hal ini menunjukkan ITIL tidak melakukan pengawasan yang akan memastikan kesesuaian pengelolaan TI dengan keadaan perusahaan di masa yang akan datang.

\subsection{PERBANDINGAN COBIT DENGAN ISO/IEC 17799}

Tabel 2.2 menunjukkan bahwa ISO/IEC 17799 melakukan sebagian proses-proses pada seluruh domain COBIT. Hal ini menunjukkan ISO/IEC 17799 mempunyai spektrum yang luas dalam hal pengelolaan TI sebagaimana halnya COBIT, namun ISO/IEC 17799 tidak sedalam COBIT dalam hal detail proses-proses yang dilakukan dalam domain-domain tersebut. 
Tabel 2.2 Matriks Proses COBIT vs Standar ISO/IEC 17799 (COBIT Mapping, Overview of International IT Guidance, 2008)

\begin{tabular}{|l|l|l|l|l|l|l|l|l|l|l|l|l|l|}
\hline \multicolumn{10}{|l|}{ Proses dan Domain COBIT } \\
\hline & $\mathbf{1}$ & $\mathbf{2}$ & $\mathbf{3}$ & $\mathbf{4}$ & $\mathbf{5}$ & $\mathbf{6}$ & $\mathbf{7}$ & $\mathbf{8}$ & $\mathbf{9}$ & $\mathbf{1 0}$ & $\mathbf{1 1}$ & $\mathbf{1 2}$ & $\mathbf{1 3}$ \\
\hline PO & - & + & + & + & - & + & + & + & + & - & & & \\
\hline AI & - & + & + & + & + & + & + & & & & & & \\
\hline DS & - & + & + & + & + & - & + & + & + & + & + & + & + \\
\hline M & + & + & - & - & & & & & & & & & \\
\hline+ & Addressed \\
\hline
\end{tabular}

\subsection{PERBANDINGAN COBIT DENGAN COSO}

Tabel 2.3 Matriks Proses COBIT vs Standar COSO (COBIT Mapping, Overview of International IT Guidance, 2008)

\begin{tabular}{|l|l|l|l|l|l|l|l|l|l|l|l|l|l|}
\hline \multicolumn{10}{|l|}{ Proses dan Domain COBIT } \\
\hline & $\mathbf{1}$ & $\mathbf{2}$ & $\mathbf{3}$ & $\mathbf{4}$ & $\mathbf{5}$ & $\mathbf{6}$ & $\mathbf{7}$ & $\mathbf{8}$ & $\mathbf{9}$ & $\mathbf{1 0}$ & $\mathbf{1 1}$ & $\mathbf{1 2}$ & $\mathbf{1 3}$ \\
\hline PO & + & + & + & + & - & + & + & + & + & - & & & \\
\hline AI & + & + & + & + & + & + & + & & & & & & \\
\hline DS & + & - & + & + & + & - & + & - & + & - & + & + & - \\
\hline M & - & - & - & - & & & & & & & & & \\
\hline
\end{tabular}

Tabel 2.3 menunjukkan bahwa COSO melakukan sebagian proses di domain PO, AI, dan DS, namun tidak satupun proses pada domain M dilakukan. Hal ini menunjukkan bahwa COSO fokus kepada proses penyelarasan TI dengan strategi perusahaan, dan sangat fokus dalam hal desain dan implementasi TI. 


\section{KESIMPULAN}

Tabel 3.1 memperlihatkan bahwa model-model standar selain COBIT tidak mempunyai range spektrum yang seluas COBIT. Model-model tersebut hanya melakukan sebagian dari prosesproses pengelolaan yang ada di dalam COBIT

Tabel 3.1 Matriks Domain COBIT vs ITIL, ISO/IEC 17799, dan COSO (COBIT Mapping, Overview of International IT Guidance, 2008)

\begin{tabular}{|l|l|l|l|l|}
\hline \multirow{2}{*}{ Standar } & \multicolumn{4}{|l|}{ Domain COBIT } \\
\cline { 2 - 6 } & PO & AI & DS & M \\
\hline ITIL & 0 & + & + & - \\
\hline ISO/IEC 17799 & 0 & + & + & 0 \\
\hline COSO & + & + & 0 & - \\
\hline \begin{tabular}{l}
$+\quad \begin{array}{l}\text { Frequently addressed } \\
\text { Moderately addressed } \\
-\quad \text { Not or rarely addressed }\end{array}$ \\
\hline
\end{tabular}
\end{tabular}

Gambar 2.5 memetakan standar COBIT dengan standar lainnya dalam hal kelengkapan prosesproses TI yang dilihat dalam dua dimensi:

1. Vertical - melihat kedetailan atau kedalaman standar dalam hal teknis dan operasional.

2. Horizontal - melihat kelengkapan proses-proses TI

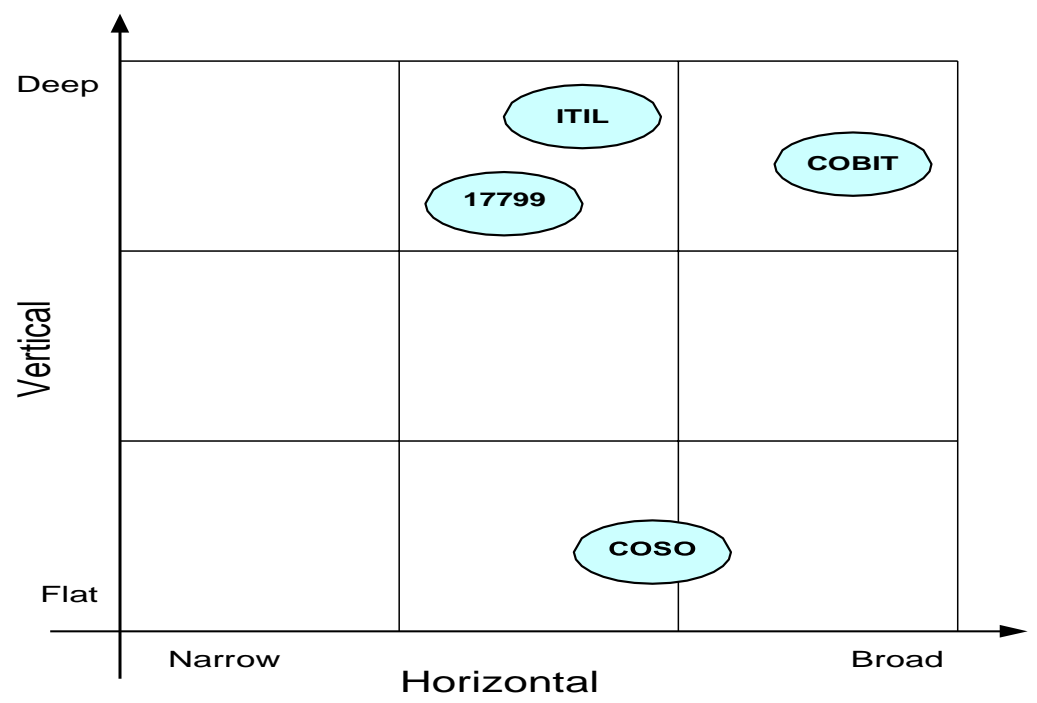

Gambar 2.5 Pemetaan COBIT terhadap ITIL, ISO/IEC 17799, dan COSO (COBIT Mapping, Overview of International IT Guidance, 2008) 
Dari Gambar 2.5 tersebut, dapat dilihat bahwa COBIT mempunyai kompromi antara dimensi horisontal dan vertikal yang lebih baik dari standar-standar lainnya. COBIT mempunyai spektrum proses TI yang lebih luas dan lebih mendetail. ITIL merupakan standar yang paling mendetail dan mendalam dalam mendefinisikan proses-proses TI yang bersifat teknis dan operasional. Sedangkan COSO mempunyai detail yang dangkal, walaupun spektrum proses teknis dan operasionalnya cukup luas.

\section{DAFTAR PUSTAKA}

[1] COBIT (2012), http://www.isaca.org/Knowledge-Center/cobit/Documents/COBIT4.pdf, “COBIT 41 Executive Summary,” Diakses 05 maret 2012.

[2] Fitrianah, Devi dan Sucahyo, Yudho G, “Audit Sistem Informasi/Teknologi Informasi Dengan Kerangka Kerja COBIT Untuk Evaluasi Manajemen Teknologi Informasi di Universitas XYZ,” Jurnal Sistem Informasi MTI-UI, Volume 4, Nomor 1, ISBN 1412-8896.

[3] Falahah (2006), "Perencanaan Tata Kelola Teknologi Informasi Berdasarkan Framework COBIT (Studi Kasus Pada Direktorat Metrologi)," Seminar Nasional Aplikasi Teknologi Informasi (SNATI), ISSN: 1907-5022.

[4] COSO (2012), “COSO and Self-Assessment,” http://www.coso.org/, Diakses 05 maret 2012.

[5] Surendro, Kridanto (2008), Rancangan Tatakelola Teknologi Informasi Untuk Pabrik Pupuk, JURNAL INFORMATIKA VOL. 9, NO. 2, NOVEMBER 2008: 115 - 121.

[6] IT Governance Institute (2008), COBIT® Mapping: Mapping of ITIL v3 With COBIT® 4.1., ISBN 978-1-60420-035-5 